\title{
Incorporation of polyphenolic peanut skin extracts and oregano essential oil into frankfurter-type sausage: effects on properties and shelf life
}

\author{
Barrionuevo, M. G., Monje, E., Enrico, M., Ryan, L., Asensio, C. M., Nepote, V. and Grosso, N. R.
}

DOI: $10.31047 / 1668.298 x \cdot v 37 . n 1.25427$

\begin{abstract}
SUMMARY
The objective of this work was to study the effect of the addition of polyphenolic peanut skin extracts (PSE) and oregano essential oil (OEO) on the microbiological, chemical, and sensory properties of frankfurter-type sausages during storage. Seven treatments were prepared: control sample (C: without additives); sausage with commercial additives (F); with OEO (O); with Runner PSE (R); with Virginia PSE (V); with OEO and Runner PSE (OR), and with OEO and Virginia PSE (OV). Consumer tests and general composition analysis were performed on the fresh products (sausages without storage). Sausages were stored at $4{ }^{\circ} \mathrm{C}$ during 37 days and samples were extracted at days $0,12,23$, and 37 for microbiological, chemical (peroxide value and conjugated dienes), and sensory descriptive analysis. All sausages had low fat content (3.36 $\mathrm{g} / 100 \mathrm{~g}$ ) and good colour, flavour and texture acceptance scores by consumers (between 57 on a 9-point hedonic scale). The absence of commercial additives (nitrite, nitrate, and other compounds) affected the sausage characteristic colour, reducing the consumer's acceptance. The treatments with natural additives had less microbiological and chemical deterioration compared to control sample. The results suggest peanut skin extracts and oregano essential oil can replace commercial additives as preservatives in sausages.
\end{abstract}

Keywords: polyphenols; peanut skin; oregano; sausages; sensory.

Barrionuevo, M. G., Monje, E., Enrico, M., Ryan, L., Asensio, C. M., Nepote, V. y Grosso, N. R. 2020. Incorporación de extractos polifenólicos de tegumento de maní y aceite esencial de orégano en salchichas tipo Frankfurt: efectos en sus propiedades y vida útil. Agriscientia 37: 41-51

\section{RESUMEN}

El objetivo del trabajo fue estudiar el efecto del agregado de extractos polifenólicos de tegumento de maní (EP) y aceite esencial de orégano (AEO) en las propiedades microbiológicas, químicas y sensoriales de salchichas tipo

Fecha de recepción: 16/09/2019; fecha de aceptación: 07/05/2020. 
Frankfurt durante el almacenaje. Se prepararon siete tratamientos: salchichas control (sin aditivos), con aditivos comerciales, con AEO, con EP Runner, con EP Virginia, con EP Runner y AEO y con EP Virginia y AEO. Inicialmente, sobre las muestras sin almacenaje, se determinó aceptabilidad por consumidores y composición química general. Las salchichas se almacenaron a $4{ }^{\circ} \mathrm{C}$ durante 37 días, y se extrajeron muestras para análisis microbiológico, químico (índice de peróxido, dienos conjugados) y sensorial descriptivo a los días 0,12 , 23 y 37. Todos los tratamientos tuvieron bajos contenidos de lípidos (3.36 $\mathrm{g} / 100 \mathrm{~g}$ ) y buenos resultados de aceptabilidad, con valores entre 5-7 (escala hedónica de 9 puntos). La ausencia de aditivos comerciales (nitrito, nitrato y otros compuestos) afectó el color característico del producto, reduciendo su aceptabilidad. Los tratamientos con aditivos naturales tuvieron menor deterioro microbiológico y químico durante el almacenaje. Los resultados sugieren que los extractos de piel de maní y el aceite esencial de orégano pueden reemplazar a los aditivos comerciales como conservantes en salchichas.

Palabras clave: polifenoles; tegumento de maní; orégano; salchichas; sensorial.

Barrionuevo, M. G. (ORCID: 0000-0003-2518-7177), Enrico, M. (ORCID: 0000-0002-3739-5339), Asensio, C. M. (ORCID: 0000-00030744-9188), Grosso, N. R. (ORCID: 0000-0002-1709-9671): Facultad de Ciencias Agropecuarias, Universidad Nacional de Córdoba, Av. Ing. Agr. Félix A. Marrone 735, (5016) Córdoba, Argentina. Monje, E. (ORCID: 0000-0002-8418-100X) y Ryan, L. (Código ORCID: 00000002-1898-6504): Escuela de Nutrición, Facultad de Ciencias Médicas, Universidad Nacional de Córdoba, Enrique Barros s/n, CU, (5016) Córdoba, Argentina. Nepote, V. (ORCID: 0000-0002-0615-5316): IMBIV-CONICET, Facultad de Ciencias Exactas, Físicas y Naturales, Universidad Nacional de Córdoba, Av. Vélez Sársfield 1611, (5016) Córdoba. Correspondence to: nrgrosso@agro.unc.edu.ar

\section{INTRODUCTION}

The frankfurter-type sausage (from the German city of Frankfurt) is a cooked sausage, prepared from pork or pork and beef, with the addition of bacon, salt and spices, scalded and then smoked to obtain a pale pink-to-brown homogeneous surface (Feiner, 2006).

The colour of meat products is an important quality attribute, which influences consumer acceptance (Pinzon-Zarate, Hleap-Zapata and Ordóñez-Santos, 2015). The red colour results as a consequence of biochemical reactions between oxygen and meat natural compounds such as myoglobin and haemoglobin; and by the action of external agents such as nitrates and nitrites (Eyiler and Oztan, 2011; Hermann, Grandy and DuedahlOlesen, 2015). Besides the ability to provide colour to meat products, nitrites have antioxidant properties, acting as synthetic-chemical preservatives. However, there is a trend to reduce the use of nitrite in the meat industry because, under appropriate conditions of $\mathrm{pH}$ and temperature, it reacts with amines forming nitrosamines and other toxins that may be carcinogenic (Hermann et al., 2015).

The demand for natural additives has grown over the last few years, mainly due to the benefits associated with numerous compounds and the potential risk of syntheticones (Pinzon-Zarate et al., 2015; Solymosi, Latruffe, Morant-Manceau and Schoefs, 2015). Natural colouring compounds are an alternative to improve meatproduct colour and to reduce the use of nitrites and other synthetic additives. Many natural phenolic compounds can contribute with red colour and also display antioxidant and antimicrobial properties for increasing the shelf life of these kinds of products (EyilerandOztan, 2011; Pinzon-Zarate et al., 2015; 
Feng, Sebranek, Lee and Ahn, 2016).

Peanut skins are a residue obtained in high amounts from the peanut industry. They are rich in polyphenolic compounds (Larrauri, Zunino, Zygadlo, Grosso and Nepote, 2016b) with a characteristic dark red appearance, water solubility and antioxidant properties proved in various food systems (Yu, Ahmedna and Goktepe, 2010; Larrauri et al., 2013; 2016a, b). Therefore, meat products such as sausages turn out to be an interesting food to incorporate those natural compounds.

On the other hand, essential oils from aromatic species are known for possessing potential as natural preservatives, being effective against the development of a range of microorganisms (Rodriguez-Garcia et al., 2016) and preventing oxidation reactions (Quiroga et al., 2013). The oregano (Origanum vulgare L.) leaves and essential oil have been used for centuries because of its medicinal properties and positive effects on human health, attributed to its antioxidant activity (Morshedloo, Salami, Nazeri, Maggi and Craker, 2018). Phenolic compounds, such as thymol and carvacrol, are characteristic of oregano essential oil and both have antioxidant properties (Quiroga et al., 2013) and a strong antimicrobial activity (Asensio, Grosso and Juliani, 2015).

Due to the antimicrobial and antioxidant activities of oregano essential oil and the characteristic red colour and antioxidant potential of peanut skin extracts, the combined use of both natural products could provide enhanced preservative effect in sausagesas substitutes for commercial additives. Therefore, the objective of this work was to study the effect of the addition of polyphenolic extracts of peanut skinsand oregano essential oil on the microbiological, chemical, and sensory properties of frankfurter-type sausages during storage.

\section{MATERIAL AND METHODS}

\section{Materials}

Peanut skins were manually separated from Virginia and Runner peanuts, crop 2018, provided by "Criadero El Carmen" (General Cabrera, Córdoba, Argentina). Before manual blanching, peanut kernels were heated at $90^{\circ} \mathrm{C}$ for 20 minutes to facilitate skin removal.

Leaves of oregano (Origanum vulgare L.) were collected in 2016 from the experimental station of the Facultad de Ciencias Agropecuarias, Universidad Nacional de Córdoba (Córdoba, Argentina).

Commercial additives were provided by
Bernesa S. A. (Buenos Aires, Argentina): Bernecol ${ }^{\circledR}$ (mixture of neutral sodium pyrophosphate, sodium tripolyphosphate, sodium metaphosphate, sodium hexametaphosphate, and sodium pyrophosphate), Salox $\mathrm{FX}^{\circledR}$ (dextrose, ascorbic acid, and sodium erythorbate), and Bernesal $^{\circledR}$ (sodium chloride, sodium nitrite and nitrate).

\section{Phenolic compound extraction from peanut skins}

Phenolic compounds were extracted from defatted peanut skins (Runner and Virginia varieties) using ethanol $70 \%$, at $1 \mathrm{~g} / 15 \mathrm{~mL}$ solid/ liquid ratio, by maceration in darkness at room temperature for $24 \mathrm{~h}$ (Larrauri et al., 2016b). The extracts were filtered through Whatman ${ }^{\circledR 1}$ paper and solvent was removed under reduced pressure in a rotary evaporator. Total phenolic content was determined following the Folin-Ciocalteu method and the results were expressed as $\mathrm{mg}$ gallic acid equivalent (GAE)/g (Larrauri et al., 2016b). Total flavonoids content was determined with the $\mathrm{AlCl}_{3}$ method measuring absorbance at $367 \mathrm{~nm}$. The results were expressed as mg quercet in $(\mathrm{QE}) / \mathrm{g}$ sample (Larrauri et al., 2016b).

\section{Oregano essential oil extraction and composition}

The essential oil was extracted for $1 \mathrm{~h}$ in a Clevenger-type apparatus, dried with anhydrous sodium sulphate and kept in dark glass flask at $-18{ }^{\circ} \mathrm{C}$ until used. The essential oil was analysed by GC-MS in PerkinElmer Q-700 equipment coupled with an ion trapmass detector (Shelton, USA). Acolumn DB-5 (30 m, 0.25 mm i.d. and $0.25 \mathrm{~m}$ coating thickness) was used. Helium (flow rate $0.9 \mathrm{~mL} / \mathrm{min}$ ) was the carrier gas. The temperature program was $3 \mathrm{~min}$ at $60^{\circ} \mathrm{C}$, a rate of $4{ }^{\circ} \mathrm{C} / \mathrm{min}$ and $240{ }^{\circ} \mathrm{C}$ final temperature. The injector was held at $250{ }^{\circ} \mathrm{C}$. Ionization was done by electron impact at $70 \mathrm{eV}$. The compounds from the essential oil were identified by comparing their retention index and mass spectra with published data, libraries NIST and Adams. Co-injection of authentic standards (Sigma, St. Louis, USA) was also used for identification of the main components. Fenchone $(0.1 \mathrm{mg} / \mathrm{mL}$ dichloromethane) was used as internal standard. The quantitative composition was obtained by peak area normalization, and the response factor for each component was considered to equal 1 (Quiroga et al., 2013). 


\section{Sausage preparation and storage}

Frankfurter sausages were prepared by a commercial manufacturer from Villa General Belgrano (Córdoba, Argentina), according to the traditional procedure, as described by Feng, Sebranek, Lee and Ahn (2016). The sausage basic paste (SBP) was prepared with lean beef meat trim (25 g/100g), pork meat $(41,5 \mathrm{~g} / 100 \mathrm{~g})$, wheat gluten (3.5 g/100g), corn starch $(7 \mathrm{~g} / 100 \mathrm{~g})$, seasonings (1.5 g/100g) (garlic, cumin, pepper, oregano leaves, smoke and sausage flavourings), ice/water (20 g/100g), salt (1.5 g/100g) and Berneco ${ }^{\otimes}(3 \mathrm{~g} /$ $\mathrm{kg}$ ). The frozen lean beef meat and pork meat were chopped and mixed with the ice/water, gluten, starch, seasonings, Bernecol ${ }^{\circledR}$, and salt until the temperature reached $4-5^{\circ} \mathrm{C}$.

Seven sausage treatments from SBP were prepared: control sample that was SBP without any additives (C); SBP with commercial additives: $2 \mathrm{~g} /$ $\mathrm{kg} \mathrm{Salox} \mathrm{FX}{ }^{\circledR}$, and $3 \mathrm{~g} / \mathrm{kg} \mathrm{Bernesal}^{\circledR}$, (F); SBP with $0.02 \mathrm{~g} / 100 \mathrm{~g}$ oregano essential oil (O); SBP with 0.2 g/100g Runner phenolic extract (R); SBP with 0.2 $\mathrm{g} / 100 \mathrm{~g}$ Virginia phenolic extract (V); SBP with 0.02 $\mathrm{g} / 100 \mathrm{~g}$ oregano essential oil and $0.2 \mathrm{~g} / 100 \mathrm{~g}$ Runner extracts (OR), and SBP with $0.02 \mathrm{~g} / 100 \mathrm{~g}$ oregano essential oil and $0.2 \mathrm{~g} / 100 \mathrm{~g}$ Virginia extracts (OV).

The concentration of natural additives (oregano essential oil and peanut skin extracts) were chosen according to previous tests and published works, with the objective of achieving protective activity with the minimum impact on the sensory characteristics of the products (Larrauri et al., 2016a).

Each final treatment mixture was stuffed into a natural bovine casing (38-40 mm diameter) and tied every $12 \mathrm{~cm}$. Next, all sausage treatments were smoked and cooked for $90 \mathrm{~min}$ and cooled in water at $4{ }^{\circ} \mathrm{C}$. Later on, they were re-pasteurised at $80^{\circ} \mathrm{C}$ for $20 \mathrm{~min}$ and cooled.

After cooling, the samples were vacuumpackaged and stored at $4{ }^{\circ} \mathrm{C}$. Each pack contained three frankfurters. Consumer tests and chemical composition analysis were performed on fresh products previous storage. Microbiological, chemical and sensory descriptive analysis were performed on samples extracted from storage at days $0,12,23$, and 37 .

\section{Chemical composition of fresh products}

Moisture, lipids, proteins and ashes were determined on fresh sausages ( 0 storage days) by AOAC methods (2010). Total carbohydrates were calculated by difference.

\section{Consumer acceptance and preference of fresh products}

Affective tests (consumer acceptance and preference ranking tests) were performed on fresh samples (0 storage days) using a consumer panel $(n=75)$ from Córdoba (Argentina). Subjects were selected based on age (18-65 years), people without food allergies, non-smokers, and subjects that reported consumption of sausages or similar products at least once a week. Samples were assigned with 3-digit random numbers and were served slices $5 \mathrm{~mm}$ thick. Participants were instructed to rinse their mouth with water and have a piece of unsalted crackers between samples to minimize residual effect of flavour. Consumers expressed their perceptions about colour, flavour and texture acceptance using a 9-point hedonic scale where $1=$ dislike extremely to $9=$ like extremely (Asensio, Nepote and Grosso, 2013). For preference test, consumers were asked to order the samples from lowest to highest preference (Lawless and Heyman, 2010).

\section{Microbiological analysis of products during storage}

Microbiological analyses were performed on all samples at storage day $0,12,23$ and 37 . Counts of total mesophilic aerobic bacteria (TMAB) were determined by culturing samples in TSA (Triptone Soya Agar, Britania Lab, Argentina), using the surface-spread method for quantitative enumeration. The results were expressed as colony forming units per $g$ of sausage sample (CFU/g) (FDA, USA, 2017). Counting of total yeasts and moulds (YM) was determined using SDA (Sabouraud Dextrose Agar, Britania Lab) as culture medium by pour-plated method. Plates used for counting were those containing 10100 colony forming units (CFU). All plates were incubated at $25^{\circ} \mathrm{C}$ for 5 days (ISO method 7954 , 1987). Additionally, the presence or absence of Escherichia coli, Salmonella spp. and coagulase positive Staphylococcus aureus were determined according to FDA-USA (2017).

\section{Chemical analysis of products during storage}

Fat was separated from sausage samples by Soxhlet extraction with $\mathrm{n}$-hexane for $6 \mathrm{~h}$. $\mathrm{n}$-Hexane was removed by evaporation under vacuum (Larrauri et al., 2013). Peroxide value (PV) $\left(\mathrm{meqO}_{2} /\right.$ $\mathrm{kg}$ fat) was determined on sausage fat according to AOAC (2010). Conjugated dienes (CD) were 
determined according to $\mathrm{COI}$ (2019) and expressed as extinction coefficient $\mathrm{E}(1 \%, 1 \mathrm{~cm}, 232 \mathrm{~nm})$.

\section{Sensory descriptive analysis of products during storage}

A hybrid descriptive analysis method consisting of the Quantitative Descriptive Analysis QDA ${ }^{\circledast}$ (Tragon Corp., Redwood City, USA) and the Spectrum ${ }^{\mathrm{TM}}$ analysis methods (Sensory Spectrum, Inc., Chatham, USA) was used for training and evaluation sessions as reported by Larrauri et al. (2013). Ten trained panellists (eight female and two male) participated in the descriptive analysis. All panellists had at least five years of experience making descriptive analysis in several food products. The panellists were selected according to the following criteria: people with good natural dentition, people without food allergies, nonsmokers, people between the ages of 18 and 64, people available for all sessions, people interested in participating, and people able to verbally communicate the observations regarding the product. A screening test was performed for panellist selection. Panel was trained and calibrated in 5 training sessions of $2 \mathrm{~h}$ each one. The panellists evaluated the intensity ratings of attributes for appearance (colour intensity, colour evenness), texture (hardness, chewiness, grainy), flavour (greasy, sausage, oregano, oxidised, smoke), basic tastes (sour, salty, bitter), and feeling factor (pungency). A 150-mm unstructured line scale was used for sample evaluation. During the training sessions the list of attributes and references were defined, and the attribute intensity ratings were assigned to each reference and warm-up sample (Grosso, Asensio, Grosso and Nepote, 2017). All samples were evaluated in partitioned booths at room temperature under white light. Ten grams of sausage slides were placed into plastic cups with lids coded with 3-digit random numbers. The final lists of warm-up and reference intensity ratings and definitions were posted in the booths during the test session. Panellists evaluated seven samples and a warm-up sample per session. Samples were tested using a completely randomized block design. The data were registered on paper ballots.

\section{Statistical analysis}

The experiment was carried out in three repetitions. Data were analysed using the InfoStat software, version 2017 (Di Rienzo et al., 2017). Means and standard errors were calculated for each chemical, microbiological, and sensory variable. Analysis of variance (ANOVA) and LSD Fisher's multiple range test $(\alpha=0.05)$ were performed to find significant differences between samples. Significant differences between samples from preference order test were found using the nonparametric Friedman test $(\alpha=0.05)$.

\section{RESULTS AND DISCUSSION}

\section{Oregano essential oil composition}

A total of 23 compounds ( $81.58 \%$ ) were identified in the oregano essential oil. The main monoterpenes found $(62.57 \%)$ were $\gamma$-terpinene $(25.78 \pm 0.02 \%)$, thymol $(19.97 \pm 0.22 \%)$, terpinene-4-acetate $(9.38$ $\pm 0.05 \%)$, and o-cymene $(7.44 \pm 0.12 \%)$. Those compounds are characteristic of oregano and have been observed by other researchers in different oreganos from Argentina (Quiroga et al.,2013; Asensio et al., 2015). Other minor compounds identified in this essential oil were $\alpha$-phellandrene, $\alpha$-pinene, camphene, $\beta$-pinene, decane, terpinolene, limonene, 2,6-nonadien-1-ol, borneol, $\alpha$-terpineol, thymol methyl ether, carvacrol methyl ether, carvacrol, $\beta$-bourbonene, caryophyllene, $\alpha$-humulene, germacrene $D, \alpha$-himachalene, and $\delta$-cadinene. Thymol and carvacrol are phenolic compounds with a great antioxidant activity in food products (Quiroga, Asensio and Nepote, 2015).

\section{Phenolic and flavonoid contentsof peanut skins}

Virginia had higher phenolic content (995 \pm $75 \mathrm{mg} \mathrm{GAE} / \mathrm{g}$ ) than Runner peanut skin extracts $(727 \pm 68 \mathrm{mg}$ GAE$/ \mathrm{g})$, with significant differences $(\alpha=0.05)$. On the other hand, both extracts showed similar flavonoid content: Runner 76,31 $\pm 2,20$ and Virginia 78,48 $\pm 1,18 \mathrm{mg} \mathrm{QE} / \mathrm{g}$. Comparable polyphenol and flavonoid contents were found in previous works on Runner peanut skins from Argentina (Larrauri et al., 2016b). Those authors reported phenolic acids, flavonoids and stilbenes in Runner peanut skin extracts. The major components found were procyanidin dimer types A and B, proanthocyanidin dimer, catechin, quercetin, and epi-catechin (Larrauri et al., 2016b).

Other authors reported higher phenolic contents and antioxidant activity in Virginia than in other types of peanut skins (Spanish and Valencia) from Thailand (Chuenchom, Swatsitang, Senawong, and Jogloy, 2016). According to the results found in the present work, Virginia could have higher antioxidant activity than Runner extract. 


\section{Chemical composition of fresh products}

The main components found in the sausages were moisture $(68.47 \pm 0.40 \mathrm{~g} / 100 \mathrm{~g})$ and proteins $(12.63 \pm 0.64 \mathrm{~g} / 100 \mathrm{~g})$. On the other hand, sausages had low fat $(3.36 \pm 0.26 \mathrm{~g} / 100 \mathrm{~g})$ and ash $(2.46 \pm 0.26 \mathrm{~g} / 100 \mathrm{~g})$ contents. The low fat content was because sausages were made using lean meat, without fat addition, and with gluten and starch. Other authors reported frankfurters with 1829fat, 11-12 protein, 52-65 moisture, and 3.0-3.5 g/100 g ash (Feng et al., 2016; Horita et al., 2016). Some researcher, focused on trends to reduce the consumption of animal fats, used different compounds (carrageenans, starch, inulin, pectin) to obtain low-fat frankfurters reaching fat contents lower than $10 \mathrm{~g} / 100 \mathrm{~g}$ (Cierach, ModzelewskaKapitula and Szacilo, 2009; Mendez-Zamora et al., 2015).

\section{Consumer acceptance and preference of fresh products}

Significant differences in consumer acceptance were detected among the treatments $(\alpha=0.05)$ (Figure 1). The colour acceptance was higher in sample $F$ with a value of 7.4 in the 9 point-scale, followed by $\mathrm{O}$ (6.0). The flavour acceptance was higher in $F(7.5)$ and lower in OV (5.9) sausages. With respect to the texture acceptance, it was greater in $F(7.3)$ than in the rest of the samples (between 6.3-6.7). The sausage preferences by consumers are summarised in Table 1. The

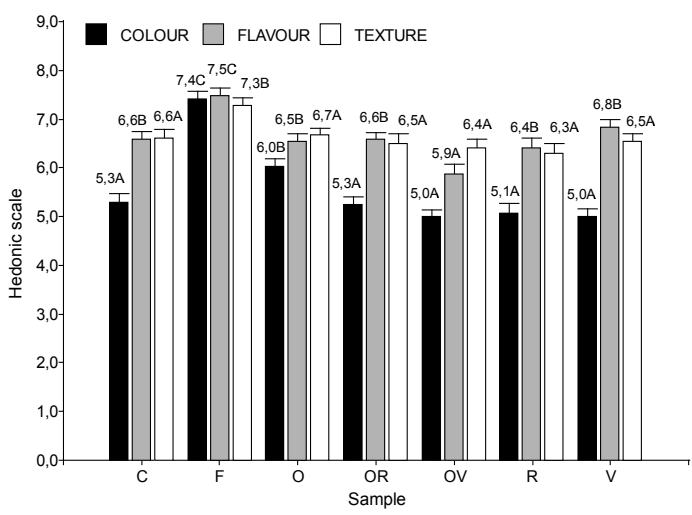

Figure 1. Consumer acceptance (means and standard errors, $n=70$ ) for colour, flavour and texture of fresh sausage samples (zero storage days): C (control), F (Frankfurter), O (Oregano), R (Runner), V (Virginia), OR (Oregano-Runner), OV (OreganoVirginia). For each attribute, means followed by different letters indicate significant differences between treatments (ANOVA and test LSD, $\alpha=0.05$ )
Table 1. Consumer preference ranking of fresh sausage samples (zero storage days)

\begin{tabular}{lcc}
\hline Sausage sample & Rank mean & ${ }^{*}$ \\
\hline Frankfurter & 1,40 & $\mathrm{~A}$ \\
Control & 3,04 & $\mathrm{~B}$ \\
Runner & 3,44 & $\mathrm{~B}$ \\
Oregano & 4,12 & $\mathrm{C}$ \\
Oregano-Runner & 5,10 & $\mathrm{D}$ \\
Virginia & 5,28 & $\mathrm{D}$ \\
Oregano-Virginia & 5,62 & $\mathrm{D}$ \\
\hline
\end{tabular}

${ }^{*}$ Rank means in the column followed by different letters indicate significant differences between samples ( $n=70$, Friedman test, $\alpha=0.05$ )

samples showed significant differences $(\alpha=0.05)$, with a decreasing order of preference of $\mathrm{F}>\mathrm{C}$ and $\mathrm{R}>\mathrm{O}>\mathrm{OR}, \mathrm{V}$ and $\mathrm{OV}$.

The consumer tests showed low-fat frankfurter sausages were highly accepted by consumers for colour, flavour and texture. The sample with commercial additives showed better results in the analysed attributes (colour, texture and flavour). However, the remaining samples had positive acceptance ratings $(\geq 5)$, and none were rejected by the consumers.

Other authors reported similar consumer acceptance results for sausages, to those found in the current study. Seo, Kang, Cho, Van Ba and Seong (2015) documented consumer acceptance scores of about 4-5 points (7-point hedonic scale) for various sausage treatments. Some authors mentioned significantly higher consumer acceptance ratings (colour, texture and flavour) for low-fat frankfurters with carrageenan (Cierach et al., 2009) and with inulin (Mendez-Zamora et al., 2015) than the regular product. Eyilerand Oztan (2011) studied the impact of tomato powder on frankfurters with low nitrite level. They stated that the addition of tomato powder increased the internal and external colour scores, and the frankfurters were found to be more acceptable than the control sample. Busatta, Mossi, Alves Rodrigues, Cansian and de Oliveira (2007) revealed that acceptance improved as the oregano essential oil concentration was reduced in sausages.

\section{Microbiological analysis of products during storage}

All samples at zero storage dayshad low total mesophilic aerobic bacteria (TMAB, average of all samples $<100 \mathrm{CFU} / \mathrm{g}$ ) and total yeasts and moulds (YM, average <100 CFU/g), without significant differences among treatments. Both microbiological quality indicators were lower than 
the limits established by the Argentinean Food Codex $(<10,000 \mathrm{CFU} / \mathrm{g}$ for TMAB, and $<100 \mathrm{CFU} / \mathrm{g}$ for YM) for all samples during storage (CAA, 2019). Additionally, pathogenic microorganisms (E. coli, Salmonella spp. and Staphylococcus aureus) were not detected in samples during storage.

The YM did not significantly increase during storage. In contrast, the TMAB increased throughout storage (Figure 2). From day 23 of storage $(\alpha=0.05)$, significant differences among treatments were observed. At the end of storage (37 days), $\mathrm{C}$ had a higher TMAB $\left(11.67 \times 10^{2} \mathrm{CFU} / \mathrm{g}\right)$ than the other sausages. Significant differences were not detected among $F$ (5.33), O (5.00), V (3.67), and R (3.00) samples and among V, R, OR (2.00) and OV (1.67). The control sample had a higher TMAB increase compared to the other samples during storage. These results suggest that the addition of commercial additives in sample $\mathrm{F}$ and natural compounds (oregano essential oiland peanut skin extracts) in the other samples provide a protective effect against the development of aerobic bacteria. The best outcome was evidenced in samples with the combined addition of oregano essential oiland peanut skin extracts (OV and OR).

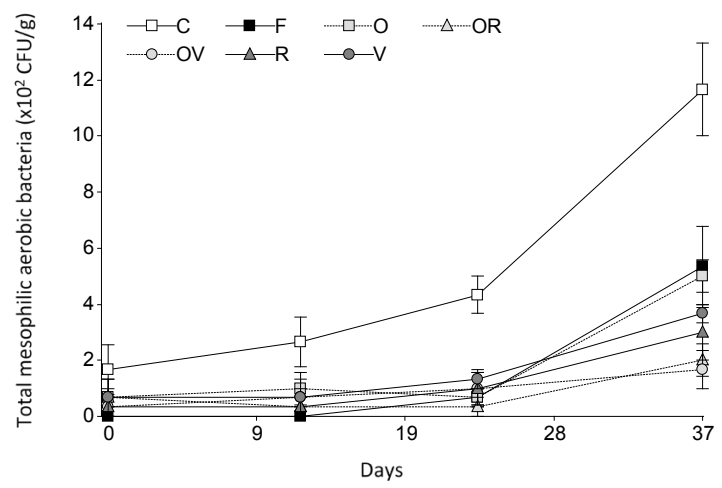

Figure 2. Microbiological analysis (total mesophilic aerobic bacteria) of sausage samples during storage at $4^{\circ} \mathrm{C}$ : $\mathrm{C}$ (control), F (Frankfurter), O (Oregano), R (Runner), V (Virginia), OR (Oregano-Runner), OV (Oregano-Virginia). Means and standard errors $(n=3)$

In comparison, other authors also reported low microbiological growth in frankfurters stored at different conditions during a longer period than the current study (Horita et al., 2016). Some authors highlighted the antimicrobial activity of oregano (O. vulgare) essential oil against several bacteria in fresh sausages (Busatta et al., 2007) and against surface fungi in fermented sausages (Chavez-Lopez et al., 2012). Yu et al. (2010) studied the potential of phenolic peanut skin extractas an antioxidant and antibacterial agent in cooked and raw ground beef. Peanut skin extract demonstrated the complete inhibition of test bacteria (Bacillus subtilis, Salmonella typhimurium, S. aureus, Streptococcus faecalis and E. coli) at a concentration of $0.4 \%$ or higher. However, the antimicrobial effect of these extracts in ground beef was less potent.

\section{Chemical analysis of products during storage}

During storage, the PV increased slightly in C, F, $R$ and $V$ samples, showing significant differences among the various storage times and treatments (Figure 3). At the end of storage (37 days), C had a higher PV $\left(5.76 \mathrm{meqO}_{2} / \mathrm{kg}\right)$ followed by the samples $\mathrm{F}\left(3.85 \mathrm{meqO}_{2} / \mathrm{kg}\right), \mathrm{R}\left(3.85 \mathrm{meqO}_{2} / \mathrm{kg}\right)$, $\mathrm{V}$ (3.72 $\left.\mathrm{meqO}_{2} / \mathrm{kg}\right)$. A lower peroxide value was observedin OV $\left(2.30 \mathrm{meqO}_{2} / \mathrm{kg}\right)$ and OR $(2.25$ $\mathrm{meqO}_{2} / \mathrm{kg}$ ) without significant differences in their PVs (37 days). Sausages with oregano $(\mathrm{O}, \mathrm{OR}$, and OV) showed almost constant PVs throughout storage.

According to these results, sausage fat deterioration was low under these storage conditions. However, peroxide increased in C, which could indicate a higher fat oxidation tendency in the samples without additives. Consistent with the microbiological results, the samples with the combined addition of oregano and peanut skin extracts better protected the samples against lipid peroxidation.

With respect to $C D$, the values of this lipid oxidation indicator did not significantly increase during storage, and neither significant differences

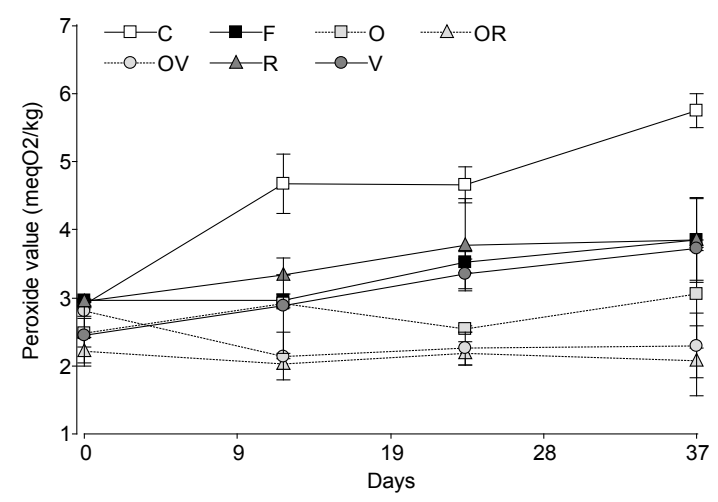

Figure 3. Peroxide values of sausage samples during storage at $4{ }^{\circ} \mathrm{C}$ : C (control), F (Frankfurter), O (Oregano), R (Runner), V (Virginia), OR (Oregano-Runner), OV (Oregano-Virginia). Means and standard errors $(n=3)$ 
between samples were registered. All samples had an average of $3.30 \pm 0.46$ conjugated dienes along the storage study.

Larrauri et al. (2013) also determined the PV and CDs in salami with peanut skin extract during storage and demonstrated that this natural additive had a protective effect against lipid oxidation on the product. A higher concentration of those natural compounds had a greater antioxidant effect on stored samples. The antioxidant activity of peanut skin extracts has been illustrated in other meat products (Yu et al., 2010) and foods (Larrauri et al., 2016a) in accordance with the results of the present work. Yu et al. (2010) reported that the addition of peanut skin extract to raw ground beef before cooking significantly inhibited the formation of peroxides in cooked ground beef during the refrigerated storage. According to those authors, the effectiveness of the extracts as antioxidant at concentration $0.06-0.10 \%$ was similar to that of $0.02 \% \mathrm{BHABHT}$. On the other hand, Larrauri et al. (2016b) studied the addition of $0.2 \%$ Runner peanut skin extracts on coated almonds that was the same concentration used in the present research. They found a significant increase in PV and CD in control samples with respect to the treatments with peanut skin extracts during storage.

\section{Sensory analysis of products during storage}

The intensity ratings of sensory attributes of fresh sausages (storage day 0 ) are shown in Table
2. Initially (day 0), significant differences among samples were found in appearance attributes (colour intensity and colour evenness), and in the oregano flavour. F sample had a higher colour intensity (31.50) and evenness (115.63) than the other samples $(p<0.05)$. $C$ and $O$ had similar colour intensities (25.13 and 24.44, respectively) with grater ratings $(p<0.05)$ than the samples containing peanut skin extracts ( $R, V, O R, O V)$. Oregano flavour was strongly detected in those samples with oregano essential oil $(p<0.05)$ : $O$, OR and OV $(33.75,27.00$, and 31.25 , respectively) without significant differences among them.

The texture attributes, such as hardness, chewiness, grainy, and greasy did not show significant differences between samples in their intensity ratings. The addition of commercial additive (treatment F) increased colour intensity and evenness. However, the lack of these additives does not substantially change other attributes, such as texture and sausage flavour. Conversely, the effect observed when adding peanut skin extracts is a decrease in colour intensity.

During storage, sausages had minimal changes to their sensory attribute intensity ratings. F sample had initially higher colour intensity than the rest of the samples, and this difference was also observed throughout storage $(\alpha=0.05)$ (Figure 4 A). $\mathrm{C}$ and $\mathrm{O}$ samples presented a decrease in their colour intensity ratings $(p<0.05)$ while the rest of treatments did not show significant changes during storage (Figure $4 \mathrm{~A}$ ). Samples containing oregano essential oil (O, OR and OV) exhibited an oregano

Table 2. Intensity ratings of sensory attributes of sausage treatments on storage days 0 (fresh samples): C (control), $\mathrm{F}$ (Frankfurter), $\mathrm{O}$ (Oregano), R (Runner), V (Virginia), OR (Oregano-Runner), OV (Oregano-Virginia)

\begin{tabular}{|c|c|c|c|c|c|c|c|}
\hline $\begin{array}{l}\text { Sensory } \\
\text { attribute }\end{array}$ & $C^{*}$ & $\mathbf{F}^{*}$ & 0 * & OR * & OV * & $\mathbf{R}^{*}$ & $\mathbf{V}$ * \\
\hline olour intensity & $25,13 \pm 1,54 \mathrm{~B}$ & $31,50 \pm 1,20 \mathrm{C}$ & $24,44 \pm 2,43 B$ & $19,44 \pm$ & $19,88 \pm 1,62 \mathrm{~A}$ & $19,67 \pm 1,48 \mathrm{~A}$ & $86 \mathrm{~A}$ \\
\hline olour uniformity & $100,00 \pm$ & $115,63 \pm 2,20 B$ & $97,56 \pm 3,2$ & $91,43 \pm 3,40 \mathrm{~A}$ & $91,63 \pm 6,11 \mathrm{~A}$ & $94,00 \pm 4,99 \mathrm{~A}$ & $5,67 \mathrm{~A}$ \\
\hline Hardness & $23,50 \pm 1,92$ & $23,38 \pm 1,57$ & $26,25 \pm 2,66$ & $24,75 \pm 2,21$ & $27,13 \pm 3,06$ & $24,75 \pm 2,75$ & $25,75 \pm 2,65$ \\
\hline Chewiness & $50,88 \pm 0,64$ & $53,50 \pm 1,72$ & $51,43 \pm 1,43$ & $51,25 \pm 1,83$ & $49,29 \pm$ & 51,8 & 50,00 \\
\hline Grainy & $41,88 \pm 0,91$ & $39,13 \pm 0,97$ & $41,25 \pm 1,25$ & $41,88 \pm 1,32$ & $44,13 \pm 1,65$ & $40,63 \pm 1,13$ & $40,63 \pm 1,13$ \\
\hline Greasy & $35,00 \pm 0,94$ & $35,00 \pm 0,94$ & $33,63 \pm 1,50$ & $35,63 \pm 1,13$ & $35,00 \pm 0,94$ & $33,75 \pm 0,82$ & $34,38 \pm 1,13$ \\
\hline Sausage flavour & $84,29 \pm 1,70$ & $86,14 \pm 1,34$ & $84,67 \pm 1,05$ & $85,00 \pm 2,24$ & $83,86 \pm 1,86$ & $86,14 \pm 1,34$ & $86,25 \pm 1,83$ \\
\hline Oregano flavour & $19,17 \pm 1,70 \mathrm{~A}$ & $14,00 \pm 0,82 \mathrm{~A}$ & $33,75 \pm 5,78 \mathrm{~B}$ & $27,00 \pm 4,00 \mathrm{~B}$ & $31,25 \pm 4,29 B$ & $15,20 \pm 0,16 \mathrm{~A}$ & $16,60 \pm 0,84 \mathrm{~A}$ \\
\hline Oxidised flavour & $0,00 \pm 0,00$ & $0,00 \pm 0,00$ & $0,00 \pm 0,00$ & $0,00 \pm 0,00$ & $0,00 \pm 0,00$ & $0,00 \pm 0,00$ & $0,00 \pm 0,00$ \\
\hline Sour & $14,63 \pm 0,38$ & $14,75 \pm 0,77$ & $16,25 \pm 1,25$ & $15,75 \pm 0,49$ & $15,38 \pm 0,38$ & $14,38 \pm 0,84$ & $15,38 \pm 0,38$ \\
\hline Salty & $47,63 \pm 1,39$ & $48,75 \pm 2,27$ & $50,38 \pm 1,93$ & $48,75 \pm 0,82$ & $48,13 \pm 1,32$ & $51,88 \pm 1,88$ & $52,50 \pm 1,89$ \\
\hline itter & $14,88 \pm 0,48$ & $14,63 \pm 0,38$ & $17,25 \pm 1,86$ & $\pm 0,42$ & $15,63 \pm 0,42$ & $15,00 \pm 0,00$ & $15,75 \pm 0,49$ \\
\hline cy & $34,25 \pm 1,62$ & $32,88 \pm 1,14$ & $38,75 \pm 2,27$ & $38,50 \pm 1,82$ & $38,50 \pm 1,56$ & $35,75 \pm 1,95$ & $36,38 \pm 0,80$ \\
\hline moked & $38,13 \pm 1,88$ & $39,75 \pm 1,54$ & $41,25 \pm 2,27$ & $41,25 \pm 2,06$ & $41,88 \pm 1,32$ & $42,50 \pm 1,64$ & $41,25 \pm 1,25$ \\
\hline
\end{tabular}

* Means and standard errors in each row followed by different letters indicate significant differences between samples $(n=3$, ANOVA, LSD test, $\alpha=0.05$ ). 
flavour decrease $(p<0.05)$ throughout storage from 27.00-33.75 (day 0) to 17.00-17.40 (day 37), without significant differences between samples (Figure $4 \mathrm{~B}$ ). These data suggest a loss of this attribute in these samples due to its volatilisation or decomposition during storage. Sausage flavour (Figure 4C) and the other sensory attributes
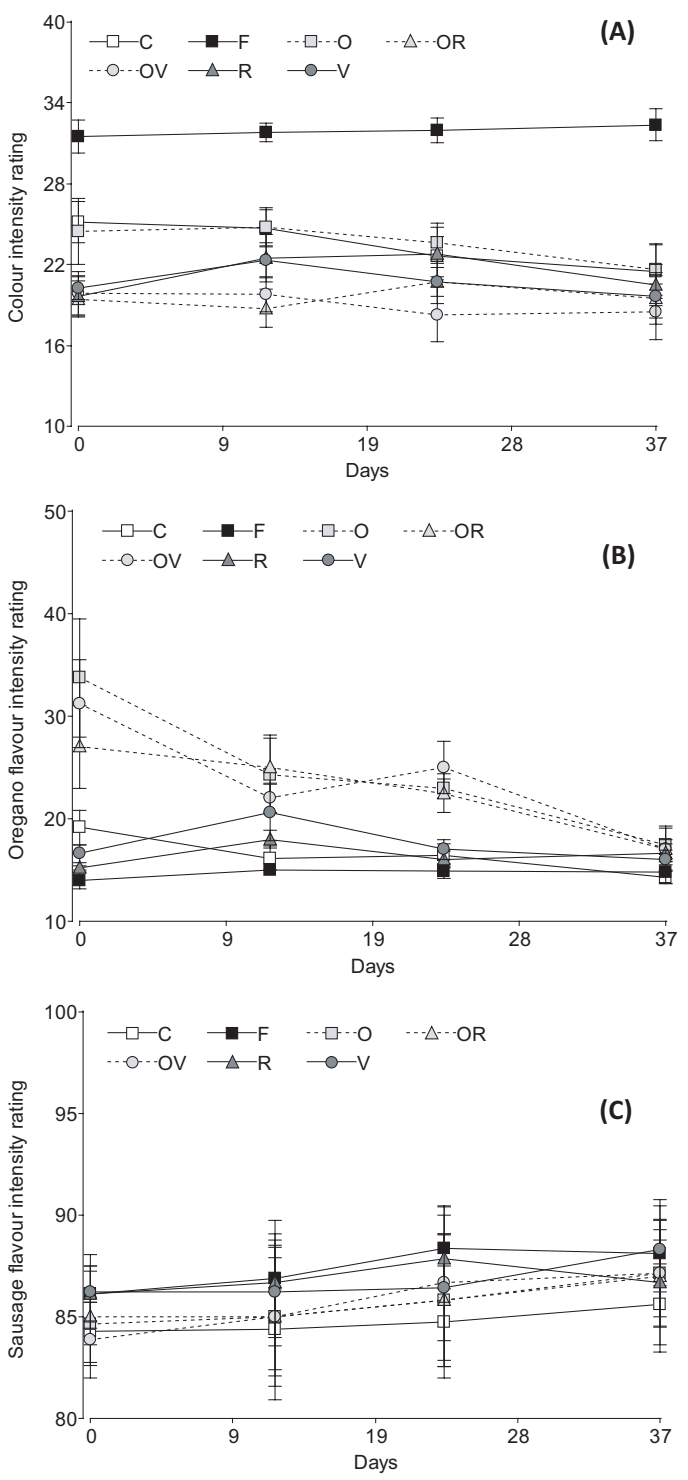

Figure 4. Sensory attribute intensity ratings of sausage samples during storage at $4{ }^{\circ} \mathrm{C}$ : (A) Colour intensity, (B) Sausage flavour, and $(C)$ Oregano flavour on sausage samples during storage at $4{ }^{\circ} \mathrm{C}$ : C (control), $\mathrm{F}$ (Frankfurter), O (Oregano), R (Runner), V (Virginia), OR (Oregano-Runner), OV (Oregano-Virginia). Means and standard errors $(n=3)$ remained almost unchanged throughout storage.

In a previous research, the effect of peanut skin extract on the sensory properties of salami during storage was studied by Larrauri et al. (2013). They reported that peanut skin extract retards lipid oxidation and preserves sensory properties of salami, prolonging its shelf life as it was found in the present study.

Other authors studied different natural additives in order to decrease the use of nitrites in sausages (Deda, Bloukas and Fista, 2007; Eyiler and Oztan, 2011; Feng et al., 2016). Deda et al. (2007) found frankfurters with reduced levels of sodium nitrite (50 and $100 \mathrm{mg} / \mathrm{kg}$ ) and $12 \%$ tomato paste had the highest redness without any negative effect on the quality of the product. Eyiler and Oztan (2011) reported that the addition of tomato powder increased the internal and external colour scores improving the consumer acceptability of frankfurters. Feng et al. (2016) found that adding $5 \%$ red wine increased the $a^{*}$ value (red-green parameter of the CIELAB color space), the textural properties (resilience, cohesiveness and springiness) of the frankfurters, as well as decreased lipid/protein oxidation of the final products. Also, the pre-converted vegetable juice powder showed the same effects as the conventional curing agents (nitrite) for typical frankfurter properties.

\section{CONCLUSIONS}

The compositions of oregano essential oil and peanut skin extracts (Runner and Virginia) suggest antimicrobial and antioxidant potential of these natural compounds to be used as food preservatives. Results from affective tests on sausages with different additives (commercial and natural) indicate consumers preferred the treatment with commercial additives (nitrates and nitrites, among others). However, they did not reject treatments with natural ones. According to trained panellists, colour was the most affected sensory attribute in treatments without commercial additives. Besides, characteristic sausage flavour and texture were not substantially altered in the products with oregano essential oil and peanut skin extracts. The addition of these natural compounds in sausages provided positive effects preventing chemical and microbiological deterioration during storage. In general, the combination of both natural additives had better protective properties than commercial ones, suggesting peanut skin extracts and oregano essential oil can replace them in sausage and other foods.

The current trend in food processing is to 
develop healthy food products without affecting the environment. Therefore, the use of peanut skins that are a waste generated by the peanut industry constitutes an interesting alternative as a raw material to prepare natural food additives.

\section{ACKNOWLEDGMENTS}

This work was financed with grants from Secretaría de Ciencia y Tecnología de la Universidad Nacional de Córdoba (SeCyT-UNC) and Consejo Nacional de Investigaciones Científicas y Técnicas (CONICET).

\section{REFERENCES}

Association of Official Agricultural Chemists (AOAC) (2010). Official Methods of Analysis of the AOAC. $18^{\text {th }}$ Ed. Gaithersburg: AOAC International.

Asensio, C., Nepote, V. and Grosso, N. R. (2013). Consumers' acceptance and quality stability of olive oil flavoured with essential oils of different oregano species. International Journal of Food Science and Technology, 48 (11), 2417-2428. doi:10.1111/ ijfs. 12233

Asensio, C. M., Grosso, N. R. and Juliani, H. R. (2015). Quality characters, chemical composition and biological activities of oregano (Origanum spp.) essential oils from central and southern Argentina. Industrial Crops and Products,63, 203-213. doi. org/10.1016/j.indcrop.2014.09.056

Busatta, C., Mossi, A. J., Alves Rodrigues, M. R., Cansian, R. L. and de Oliveira, J. V. (2007). Evaluation of Origanum vulgare essential oil as antimicrobial agent in sausage. Brazilian Journal of Microbiology, 38 (4), 610-616.

Código Alimentario Argentino (CAA). (2019). Capítulo VI: Artículos 247 al 519 - Alimentos Cárneos y Afines. Argentina: ANMAT, Ministerio de Salud. Retrieved from: https://www.argentina.gob.ar/anmat/ codigoalimentario

Chaves-López, C., Martin-Sánchez, A. M., FuentesZaragoza, E., Viuda-Martos, M., Fernández-López, J., Sendra, E., ... Pérez Alvarez, J. A. (2012). Role of oregano (Origanum vulgare) essential oil as a surface fungus inhibitor on fermented sausages: evaluation of its effect on microbial and physicochemical characteristics. Journal of Food Protection, 75 (1), 104-111. doi.org/10.4315/0362-028X.JFP-11-184

Chuenchom, P., Swatsitang, P., Senawong, T. and Jogloy S. (2016). Antioxidant capacity and phenolic content evaluation on peanut skins from 3 peanut types. Chiang Mai Journal of Science, 43, 123-137.
Cierach, M., Modzelewska-Kapitula, M. and Szacilo, K. (2009). The influence of carrageenan on the properties of low-fat frankfurters. Meet Science, 82 (3), 295-299. doi.org/10.1016/j.meatsci.2009.01.025

Consejo Oleícola Internacional (COI) (2019). Method of analysis: Spectrophotometric investigation in the ultraviolet Document COI/T 20/Doc no 19/Rev 5. Madrid: International Olive Oil Council. Retrieved from: https://www.internationaloliveoil.org/wp-content/ uploads/2019/11/Method-COI-T.20-Doc.-No-19Rev.-5-2019-2.pdf

Deda, M. S., Bloukas, J. G. and Fista, G. A. (2007). Effect of tomato paste and nitrite level on processing and quality characteristics of frankfurters. Meat Science, 76 (3), 501-508. doi.org/10.1016/j.meatsci.2007.01.004

Di Rienzo, J. A., Casanoves, F., Balzarini, M. G., Gonzalez, L., Tablada, M., and Robledo, C. W. Infostat (versión 2017) [Software de cómputo] Córdoba, Argentina: Grupo InfoStat, FCA, Universidad Nacional de Córdoba. URL: http://www.infostat.com.ar

Eyiler, E. and Oztan, A. (2011). Production of frankfurters with tomato powder as a natural additive. LWTFood Science and Technology, 44 (1), 307-311. doi. org/10.1016/j.lwt.2010.07.004

FDA, United States (2017). Bacteriological Analytical Manual. Retrieved from: https://www.fda.gov/ food/foodscienceresearch/laboratorymethods/ ucm2006949.htm

Feiner, G. (2006). Meat Products Handbook, Practical Science and Technology. Cambridge: Woodhead Publishing Limited.

Feng, X., Sebranek, J. G., Lee, H. Y. and Ahn, D. U. (2016). Effects of adding red wine on the physicochemical properties and sensory characteristics of uncured frankfurter-type sausage. Meat Science, 121, 285291. http://dx.doi.org/10.1016/j.meatsci.2016.06.027

Grosso, A. L., Asensio, C. M., Grosso, N. R. and Nepote, V. (2017). Sensory Quality Preservation of Coated Walnuts. Journal of Food Science, 82 (1), 185-193. doi.org/10.1111/1750-3841.13570

Herrmann, S. S., Grandy, K. and Duedahl-Olesen, L. (2015). Formation and mitigation of $\mathrm{N}$-nitrosamines in nitrite preserved cooked sausages. Food Chemistry, 174 (1), 516-526. doi.org/10.1016/j. foodchem.2014.11.101

Horita, C. N., Farías-Campomanes, A. M., Barbosa, T. S., Esmerino, E. A., Gomes da Cruz, A., Bolini, H. M. A., ... Pollonio, M. A. R. (2016). The antimicrobial, antioxidant and sensory properties of garlic and its derivatives in Brazilian low-sodium frankfurters along shelf-life. Food Research International, 84, 1-8. doi.org/10.1016/j. foodres.2016.02.006

International Organization for Standardization (ISO). (1987). General guidance for enumeration of yeasts 
and moulds, Colony count technique at $25^{\circ} \mathrm{C}$ (Method 7954). Retrieved from: https://www.iso.org/ standard/14931.html

Larrauri, M., Barrionuevo, M. G., Riveros, C., Mestrallet, M. G., Zunino, M. P., Zygadlo, J. A., ... Nepote, V. (2013). Effect of peanut skin extract on chemical stability and sensory properties of salami during storage. Journal of the Science of Food and Agriculture, 93 (7), 17511757. doi.org/10.1002/jsfa.5965

Larrauri. M., Demaría, M. G., Ryan, L., Asensio, C. M., Grosso, N. R. and Nepote, V. (2016a). Chemical and sensory quality preservation in coated almonds with the addition of antioxidants. Journal of Food Science, 81 (1), S208-S215. doi.org/10.1111/1750-3841.13164

Larrauri, M., Zunino, M. P., Zygadlo, J. A., Grosso, N. R. and Nepote, V. (2016b). Chemical characterization and antioxidant properties of fractions separated from extract of peanut skin derived from different industrial processes. Industrial Crops and Products, 94, 964971. doi.org/10.1016/j.indcrop.2016.09.066

Lawless, H. T. and Heymann, H. (2010). Sensory evaluation of food. Principles and practices ( $2^{\text {nd }}$ ed.). New York, Unites States: Springer. doi.org/10.1007/978-1-44196488-5

Méndez-Zamora, G., García-Macías, J. A., SantellanoEstrada, E., Chávez-Martínez, A., Durán-Meléndez, L. A., Silva-Vázquez, R. and Quintero-Ramos, A. (2015). Fat reduction in the formulation of frankfurter sausages using inulin and pectin. Food Science Technology, 35 (1), 25-31. doi.org/10.1590/1678-457X.6417

Morshedloo, M. R., Salami, S. A., Nazeri, V., Maggi, F. and Craker, L. (2018). Essential oil profile of oregano (Origanum vulgare L.) populations grown under similar soil and climate conditions. Industrial Crops\&Products, 119, 183-190. doi.org/10.1016/j.indcrop.2018.03.049

Pinzon-Zarate, L. X., Hleap-Zapata, J. I. and OrdóñezSantos, L. E. (2015). Análisis de los parámetros de color en salchichas frankfurt adicionadas con extracto oleoso de residuos de chontaduro (BactrisGasipaes). Información Tecnológica, 26 (5), 45-54. doi.
org/10.4067/S0718-07642015000500007

Quiroga, P. R., Grosso, N. R., Lante, A., Lomolino, G., Zygadlo, J. A. and Nepote, V. (2013). Chemical composition, antioxidant activity and anti-lipase activity of Origanum vulgare and Lippiaturbinata essential oils. International Journal of Food Science and Technology, 48 (3), 642-649. doi.org/10.1111/ ijfs. 12011

Quiroga, P. R., Asensio, C. M. and Nepote, V. (2015). Antioxidant effects of the monoterpenes carvacrol, thymol and sabinene hydrate on chemical and sensory stability of roasted sunflower seeds. Journal of the Science of Food and Agriculture, 95 (3), 471-479. doi. org/10.1002/jsfa.6744

Rodriguez-Garcia, I., Silva-Espinoza, B. A., OrtegaRamirez, L. A., Leyva, J. M., Siddiqui M. W., CruzValenzuela, M. R., Gonzalez-Aguilar, G. A. and Ayala-Zavala, J. F. (2016). Oregano essential oil as an antimicrobial and antioxidant additive in food products. Critical Reviews in Food Science and Nutrition, 56 (10), 1717-1727. doi.org/10.1080/10408 398.2013.800832

Seo, H-W, Kang, G-H, Cho, S-H, Ba, H. V. and Seong, P-N. (2015). Quality properties of sausages made with replacement of pork with corn starch, chicken breast and surimi during refrigerated storage. Korean Journal of Food Science of Animal Resources, 35 (5), 638-645. doi.org/10.5851/kosfa.2015.35.5.638

Solymosi, K., Latruffe, N., Morant-Manceau, A. and Schoefs, B. (2015). Food colour additives of natural origin. In Scotter, M. J. (Ed), Colour additives for foods and beverages (pp. 3-34).Cambridge, United Kingdom: Woodhead Publishing, Elsevier Ltd. doi. org/10.1016/B978-1-78242-011-8.00001-5

Yu, J., Ahmedna, M. and Goktepe, I. (2010). Potential of peanut skin phenolic extract as antioxidative and antibacterial agent in cooked and raw ground beef. International Journal of Food Science and Technology, 45 (7), 1337-1344. doi.org/10.1111/j.13652621.2010.02241.x 